\title{
Sight-reading as an important factor in the professional growth of future music teacher
}

\author{
Anna Adamyan \\ Armenian State Pedagogical University after Khachatur Abovyan | Armenia
}

\begin{abstract}
The aim of the following study is to highlight the significance of the development of sightreading skills both in the higher stages of music education implemented in the university, conservatory, and in the music career of performer-teachers. The author has examined a large number of Soviet, PostSoviet and Western studies concerning the topic with sufficient practical recommendations and methods for developing this skill. According to the results of the online questionnaire-based survey, carried out among participants, the data analyses showed that, in spite of giving importance to sight-reading, the respondents seek to pay more attention to this skill by involving it in the curricula on their own initiative. As a result, the author's hypotheses are fully supported. Besides, based on her own experience, the author confirms that sightreading provides the music teacher with a broad range of benefits leading to professional development and a good reputation among the students.
\end{abstract}

Keywords: instrumental performance; music teacher; performing skills; pedagogical skills; sight-reading. 
$\mathrm{I}$

$\mathrm{n}$ the contemporary world the creative activity of the music teacher implies many professional and pedagogical skills and abilities. So, what do we mean by saying the teacher's creative activity? Probably, within the concept of the teacher's creative activity, we mean the chance of free improvisation, extempore presentation of works, speech delivery with illustrative examples such as songs, performances and vivid descriptions in parallel with a lesson plan. At the same time, in the teaching process, it is very important for a music teacher to take into account the disposition and desires of the students and be flexible trying to provide not only materials made in advance but also perform and show the learners' favorite works. Thus, the essential part of the music teacher's activity is the performance-based activity, which means playing an instrument, singing, accompanying the school choir or ensemble. Therefore, for ensuring a proper performance, the music teacher should possess performance skills that promotes self-confidence and freedom.

It is impossible to imagine the professional abilities of a music teacher without a high level of sight-reading skill. It should be noted that sight-reading is necessary for the music teacher's activities. The music teacher may not even notice how often sight-reading is used in a professional work. Certainly, sight-reading skill is an integral part of a music teacher's activities, even without direct intention. Sight-reading is used both for the choice of teaching materials, accompanying students, and for the presentation of new musical works. So, it is necessary to analyze its role in the further development of music-teachers' professional skills. In addition to this, it is also important to try some methods and strategies for the development of sight-reading skill. What does it mean to sight-read music? It is an initial, "on-the-spot" acquaintance that a musician acquires when learning a new composition. To learn and perform each work, the performer first of all should sight-read a music. The musician's proficiency in sight-reading can make it easy to understand the composition and develop the forthcoming work on it.

Sight-reading is a complex skill based on the level of the musician's full readiness, quick orientation, and artistic intuition. The high level of sight-reading can solve such an issue for musicians and music teachers as time pressure; that allows them to master a new playlist in a short time and have complete concert activities. In the modern world, it is important for the musician to be able to respond quickly to new offers, auditions, educational programs, and in any case to create and prepare an appropriate concert program or examination materials. It is not a secret that 
performance anxiety is one of the major issues for the musician, and in many cases the lack of time can cause anxiety, even forcing the performer to reject the performance offers or beneficial suggestions.

By enhancing performers' self-knowledge, combined with the application of anxiety management strategies when under pressure, these studies show that the negative effects of performance anxiety can be reduced. Commensurate with this, performance resilience increases through improved confidence, self-belief, courage, persistence and ability to recover from mistakes (OSBORNE, 2016, p. 93).

In this context, the sight-reading can give the musician some freedom and an alternative to the tedious work of many hours, reducing some stages of learning new musical compositions. It will reduce the anxiety associated with performance and help to keep a mental balance by giving selfconfidence, and a strong belief in their own abilities.

It is no secret that many prominent musicians like List, d'Alber, Bloomenfeld, Rachmaninoff, Goldenweizer and many others have excelled in sight-reading. Looking through the pages of music history, it should be noted that in the second half of the 19th century, the requirement of sightreading was included not only in the curriculum in Russian but also in foreign authoritative music institutions. Not all places may have taken this seriously, but in institutions run by high-quality, experienced leaders, daily sight-reading was given precise attention. At the Moscow Conservatory, for instance, the demands of this field were quite serious. N.G. Rubinstein forced his students to accompany concerts by sight-reading. There is evidence that many prominent pedagogue-musicians such as N.S. Zverev, V.I. Safonov, F. M. Blumenfeld, L. V. Nikolaev, H. H. Neyhaus built their lessons on this extempore foundation. They found that sight-reading should occupy a certain place in the daily "ration" of a student-musician (TSIPIN, 1984, p. 45).

The purpose of our questionnaire-based survey is:

- To study sight-reading, its theory, and the ability to comprehend and analyze the musical score by the inner hearing. Therefore, we are going to examine the performance skills and to reveal the significance of sight-reading among performers and music teachers. According to our 
hypothesis, more attention should be paid to the sight-reading in the learning process carried out by future music teachers.

- The analysis and comparison of soviet literature and western studies to perceive the current sight-reading situation and compare it with the results of our survey.

\section{Methods}

The research methodology includes an online questionnaire-based survey sent via emails to the current students, graduates, and musicians working as music teachers who have graduated from the "music education" department of Armenian State Pedagogical University after Khachatur Abovyan. The questionnaire was created by the author via google forms and involves 8 questions with possible answers that provide detailed information on the importance and usage of sightreading in the participants' professional activities. After collecting the data, the author uses diagrams to calculate and obtain a certain picture of the issue.

\section{Discussion}

It is well known that the prominent Russian pedagogues, pianists such as KORYKHALOVA (2006), BRYANSKAYA (2005), VERCHOLAZ, (1960), YEGOROV (1953) and others have touched upon the problem of sight-reading. Western studies also have huge quantity of studies on this subject. OSBORNE (1976), STEVEN; CASSIDY (2000), KOSTKA (2000), PENTTINEN; HUOVINEN (2011), PIKE (2012), HAYWARD; GROMKO (2009) and others mainly present a number of observations and methods in their studies for developing the sight-reading skill. In our study we try to prove that the sight-reading plays a big role in the education and further development of a music teacher as it contributes to the effective work of future music teachers.

Based on our observation, some education programs don't pay close attention to sightreading. It is a spontaneous process rather than an evolving skill. Generally, nowadays the amateur music-making is in decline by giving way to audio and video recordings. As a result, musicians are not eager to play a musical instrument even for their own pleasure. On the other hand, in the 
learning process, it is important to learn the tasks by heart that attracts the student's full attention. Generally speaking, the sight-reading becomes essential only at the beginning of the learning process, especially in the early grades of music schools as a part of musical literacy. Then the sightreading gets little attention being replaced by the comprehension of assignments.

The skill of music sight-reading-the ability to read and play music at first sight-is highly valued in the field of music education. The inclusion of music sight-reading at state contests in secondary schools suggests that the ability to read and play with speed and accuracy is an important indicator of music achievement. Despite the value placed on music sight-reading at the secondary school level, auditions at college and university levels are often based solely on performance ability and don't include sight-reading (HAYWARD; GROMKO, 2009, p. 26).

Certainly, all studies mentioned above indicate the importance of sight-reading for musicians. Moreover, this should be one of the primary tasks faced by music teachers that make their functions more interesting and comprehensive. Let's consider some views on the development of sightreading skill from the Soviet and Post-Soviet as well as western studies.

The Soviet pedagogue Raisa Vercholaz (1960) notes that the sight-reading is mainly examined at the preliminary stage and she presents a number of methods for the development of sight-reading skill. Besides, in her work Raisa Vercholaz cited the major Soviet musicians' standpoints on the sight-reading skill. Here are some quotes:

Professor Mostras notes that the sight-reading should be involved in daily training as a mandatory, systematic training of a relatively simple and more complex musical compositions. He thinks that the following discipline helps the student stay focused, improves the essential musical listening skills, the sense of rhythm as well as develops the ability to accomplish difficult music assignments and succeed in chamber ensembles, orchestras, and solo performances. D.F Oistrakh advised his students to look through the music literature at least once in a week (VERCHOLAZ, 1960, p. 8).

Based on our teaching experience, it can be stated that students are often unable to read and comprehend the assigned work while mastering a new work. In many cases, they have to listen to a recording or ask the teacher to show and often explain a structure of the musical work in the classroom. This indicates the low level of self-determined work of students and the lack of some skills. However, many studies indicate that a learner's mental development only results when it is built on active and independent work. The concept of independent work is very capable, 
combining both the ability to self-orientate with unfamiliar musical material, to interpret the author's text correctly, to create a convincing performance "hypothesis" and to find effective ways to express it, embody the artistic idea, and, of course, the ability to find and critically to evaluate one's own as well as the others' performance, and other abilities (TSIPIN, 1984, p. 69).

Of course, the more the teacher develops the learner's independence and the abovementioned skills, the more the learner's aural hearing, imagination and the broader range of knowledge are formed. Since sight-reading is also linked to aural music listening and its development, therefore it can be improved. Experience shows that beginner musician who does not have a high level of technical competence also doesn't have good sight-reading, and on the contrary, a good professional musician can read well, although exceptions are also possible. So, the more the student tries to improve his/her technical apparatus, the better will be developed the sight-reading. The technical exercises, mandatory exercises may be useful and can develop specific technical formulas, making them predictable for the eye. As technical capability develops, the ability of sightreading will begin to develop, which will ensure a faster and a more stable result.

Speaking about the sight-reading skill and its development methods, it can be noted that a broad knowledge of musical, tempo, and characteristic terms is also important for developing this skill. It is important for the students to be suggested to read the notes of tempo, tone, keys, size, and meter before performing. This will at once give them some insight into the pace, nature, and other details of the composition. In some music institutions, sight-reading was included in the accompaniment class, which was certainly very useful, as it was more important for the accompanist to have a high level of sight-reading. On the other hand, the accompanying part of pieces is often written using specific texture techniques; Chords, arpeggios, gammas, and very convenient to use as teaching material.

Since sight-reading is often associated with the initial phase of music education, it is very important to provide good literary, rhythmic, and proficient reading skills at an early stage. Some studies show that the students without having some basic piano knowledge face various difficulties in reading two lines at the same time, as well as in coordination and comprehension of tonal, structural and artistic essence of musical composition.

A large number of studies indicate the importance of the development of eye contact, 
especially the ability to look straight ahead. It should be noted that different studies offer different approaches that are expressed in the following observations:

From a cognitive standpoint, sight-reading involves four components: 1. Perception (where we must decode patterns), 2. Kinesthetics (executing motor skills that have been programmed to the aforementioned patterns), 3.Memory (recognizing patterns when we see them in the score and being able to recall both the pattern and the associated motor skill quickly), 4.Problem-solving skills (improvising and guessing about what lies ahead based on context and previous experience) (PIKE, 2012, p. 24).

According to our previous studies, it is important to conduct a theoretical analysis of the piano texture, and study the musical scores in great detail, because given the insufficient independence and lack in the development of fingers, aural and visual work gains greater importance. While playing, it is important to differentiate between primary and secondary parts of the texture from an aural point of view in order to be able to make the main melody more expressive and create a background melody by means of the accompanying sounds.

Since the piano texture is extremely complex, one is occasionally required to play multiple lines with one hand; therefore, it is important to develop the competence of keeping track of multiple sounds by means of one's ears. It is important to improve the skill of 'looking ahead' in the score. The beginner must try to look ahead, to the next bars, while playing, after the whole phrases, lines and so on. The learner must start from shorter easier pieces and increase the repertoire gradually (ADAMYAN, 2018, p. 195).

According to Bryankaya (2005, p. 6), the music teacher faces a number of challenges when trying to improve the beginner piano player's sight-reading skill which is both complex and comprehensive. At first glance, it seems that the problems aren't directly related to the instrumental class and they are involved in the competence/duties of a solfege and music literacy teacher. While these problems include the development of auditory perception and sense of rhythm as well as the improvement of music-related memory, attention and other skills. No matter how important they are for solfege lessons, only instrumental classes accomplish the final synthesis of the theoretical and practical knowledge that the child acquires at music school. 
When sight-reading music, grouping individual notes into meaningful patterns and developing the associated motor skills is critical. We cannot expect that the majority of our students will learn how to chunk on their own, without explicit help from us, in the form of chunking drills that accompany sight-reading exercises. We must insist that our students sight-read each time they sit down to practice. If we do not make sight-reading a priority in our studios during lesson time, we send a strong message that being able to read at sight is not as important as performing. Since the majority of our students will not go on to become elite performers, perhaps our emphasis should place equal importance on performing adeptly and being able to play music well after very little rehearsal (or even at sight) (PIKE, 2012, p. 28).

The last quote is in line with the purpose of our study, as we emphasize the importance of sightreading skill for music teachers. Besides, not all music students become performers, and sightreading is more useful for their work (choir management, teaching, accompaniment, etc.).

Students should respond to this challenge by a 'never-say-die' attitude and a pride in their ability to make sense of a composition the first time through. The ability to sight-read gives the opportunity to double or triple the amount of literature the group can explore during the school year. The group that excels in sight-reading can prepare the compositions used in concerts, festivals, and contests in less time, avoiding some of the tedium and boredom of endless repetition” (OSBORNE et all., 1976, p. 62-63).

Both choirs and small ensembles can definitely put this idea into practice as the ability to sight-read in the rehearsal avoids long and monotonous repetitions at the beginning of learning a music composition. It should be noted that this topic needs more detailed and comprehensive study.

Lowder (1983) surveyed college faculty members and in-service teachers to determine what they believed were the most important piano skills and found that sight-reading ability was ranked second ('cadences' was first), followed by score-reading, harmonization, and accompanying (KOSTKA, 2000, p. 115)

The main purpose of this study is to prove the effectiveness of sight-reading skill for music teachers. The analysis of the results presented below is based on the responses to each question. 
Chart 1.

\begin{tabular}{|r|r|r|}
\hline $\begin{array}{r}\text { What is your occupation, position/ student, teacher, etc.? } \\
\text { The total number of respondents is } 83\end{array}$ \\
Student and accompanist \\
Choirmaster \\
Musician \\
Student and pedagogue \\
Teacher \\
Student
\end{tabular}

Chart 2.

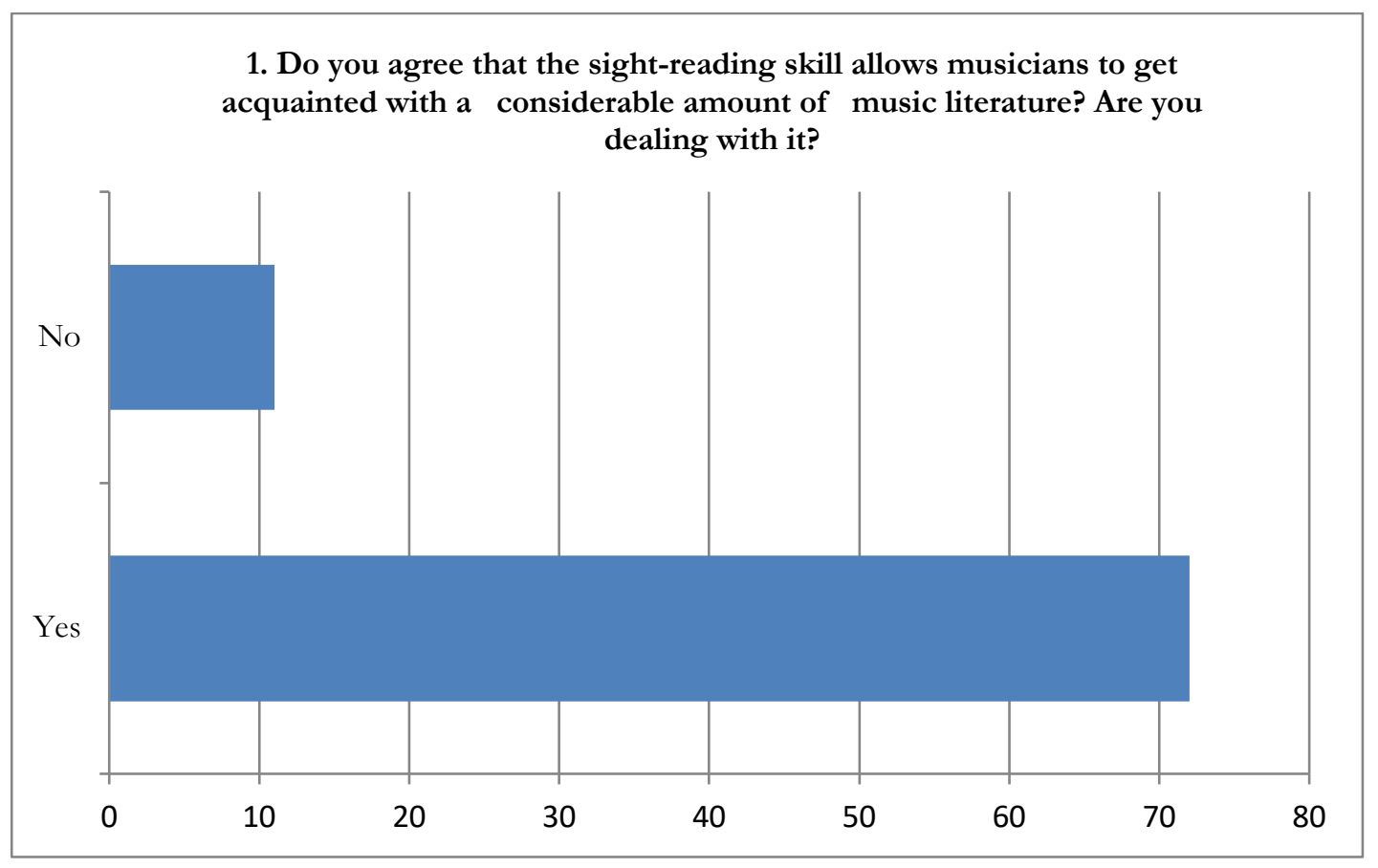


Chart 3.

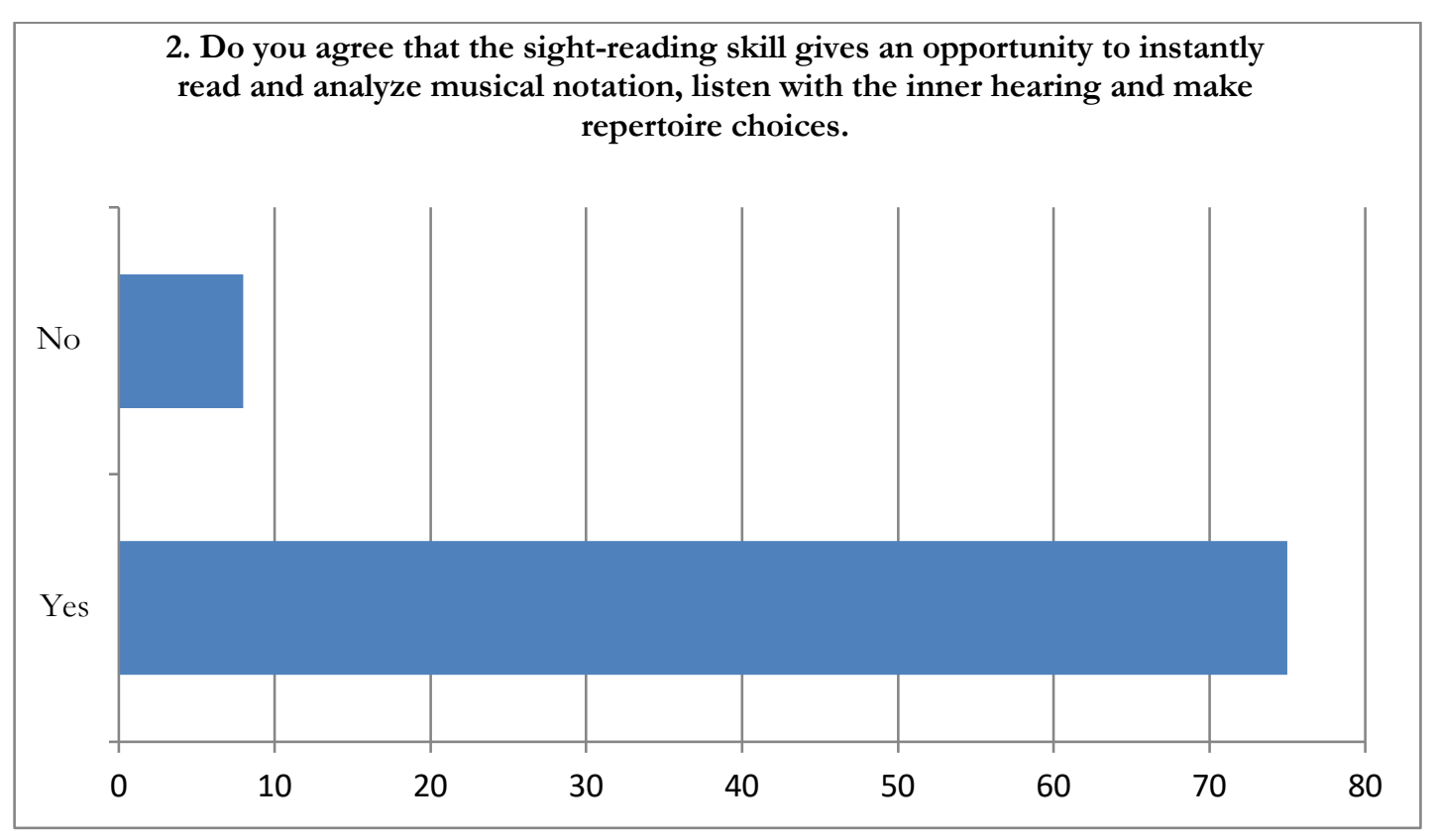

Chart 4.

3. Do you agree that the sight-reading skill allows the diversity in music performance when teaching, if you are already working (for example, to perform a new piece of music without being prepared in advance).

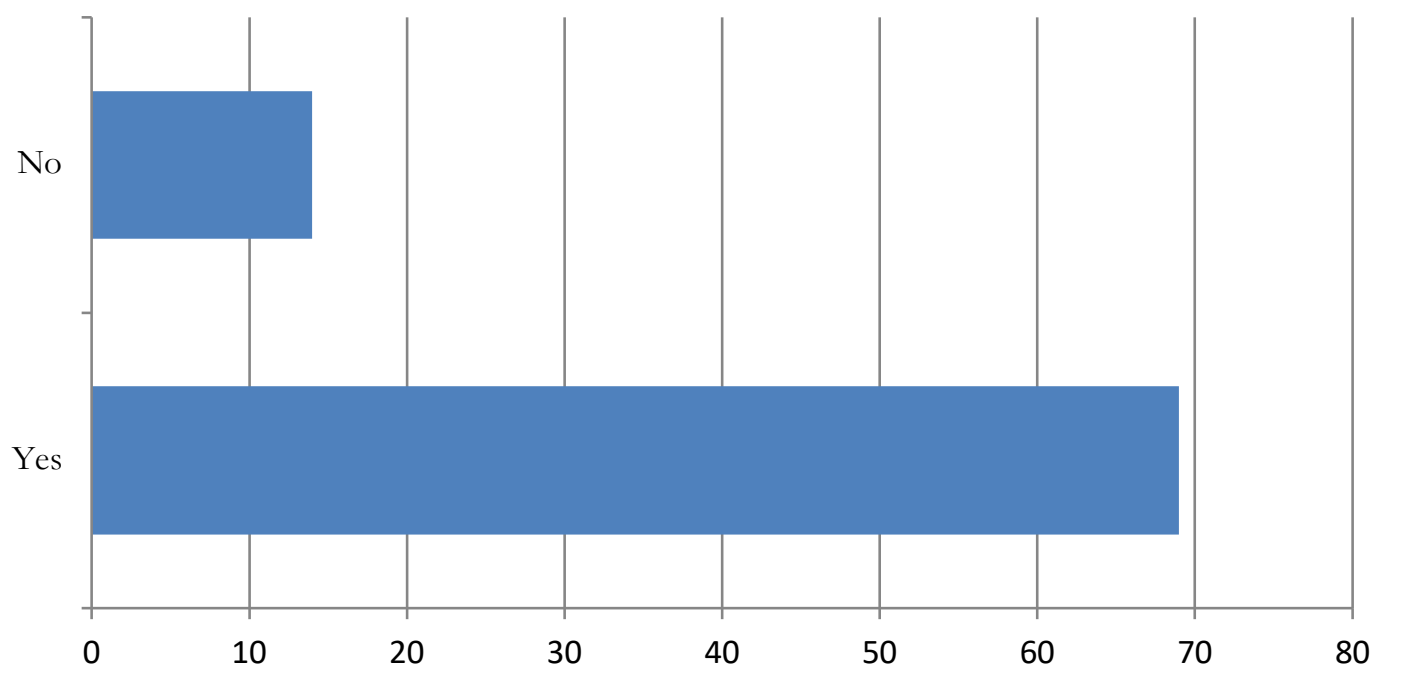


Chart 5.

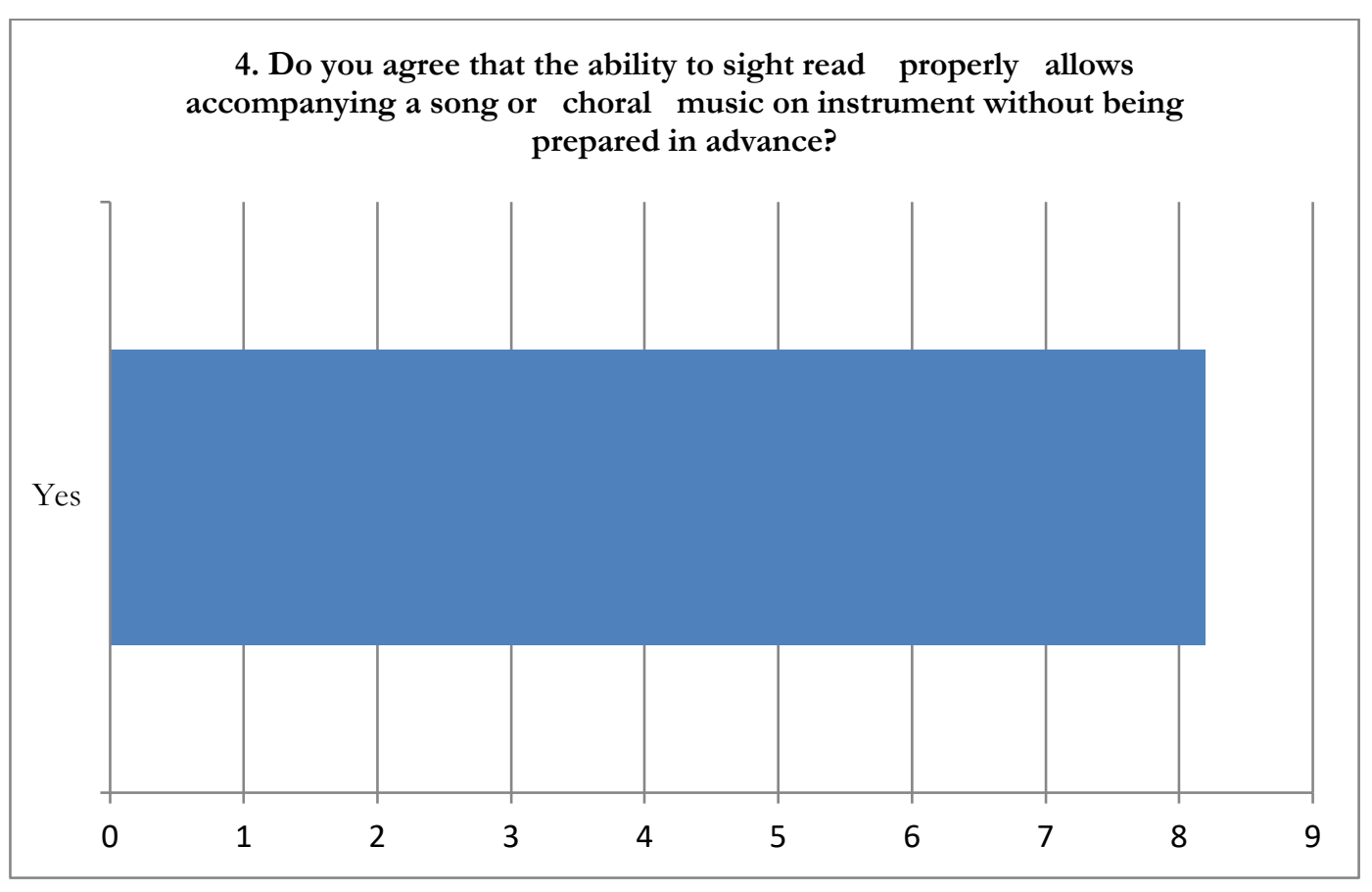

Chart 6.

5. Do you get involved in the development of sight reading and how often?

Under the lecture's guidance

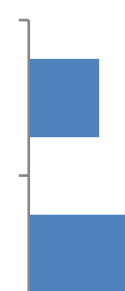

Yes,sometimes
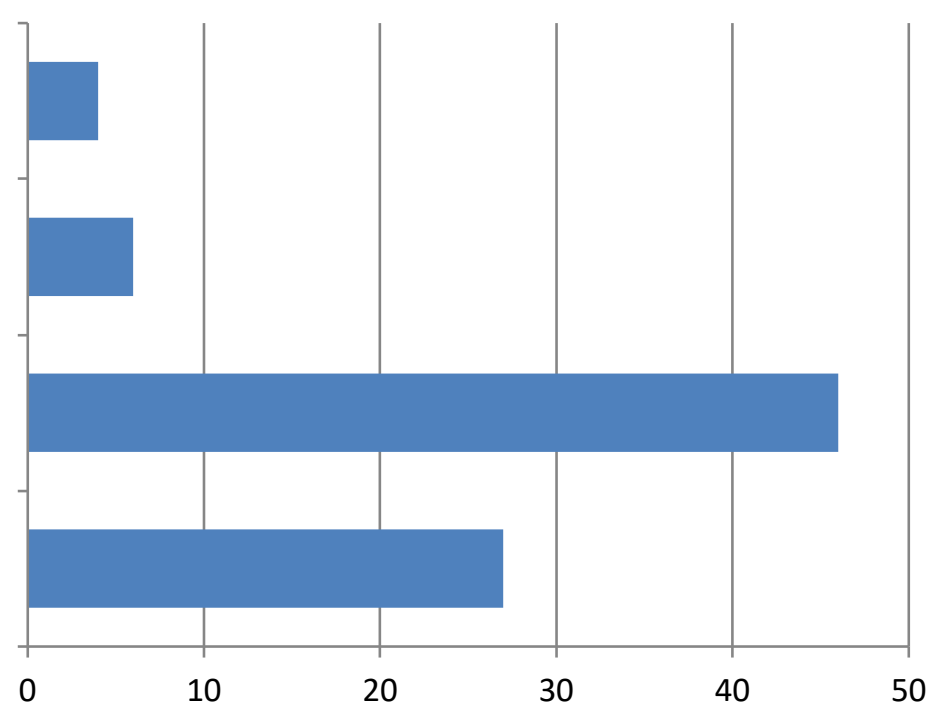
Chart 7.

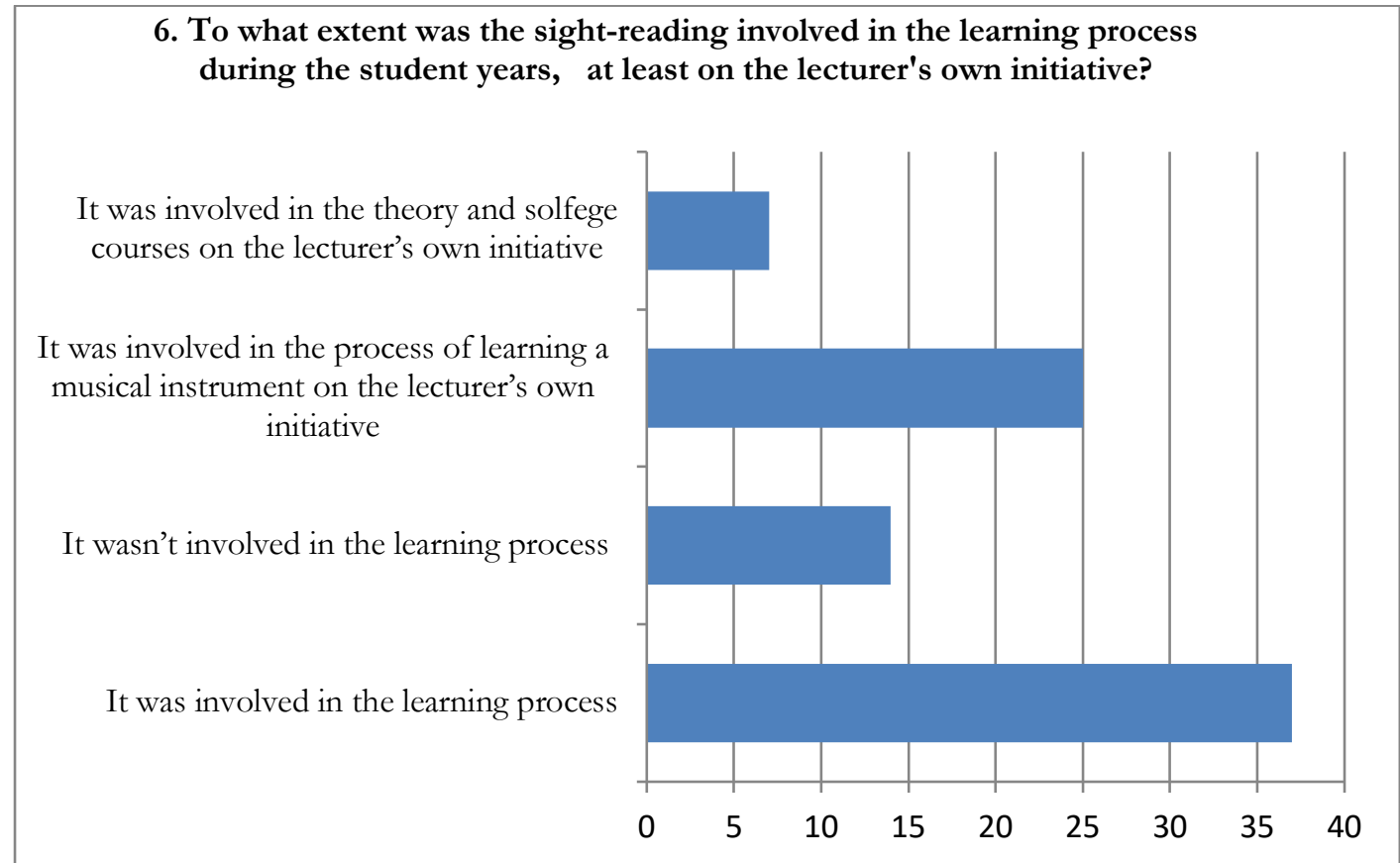

Chart 8.

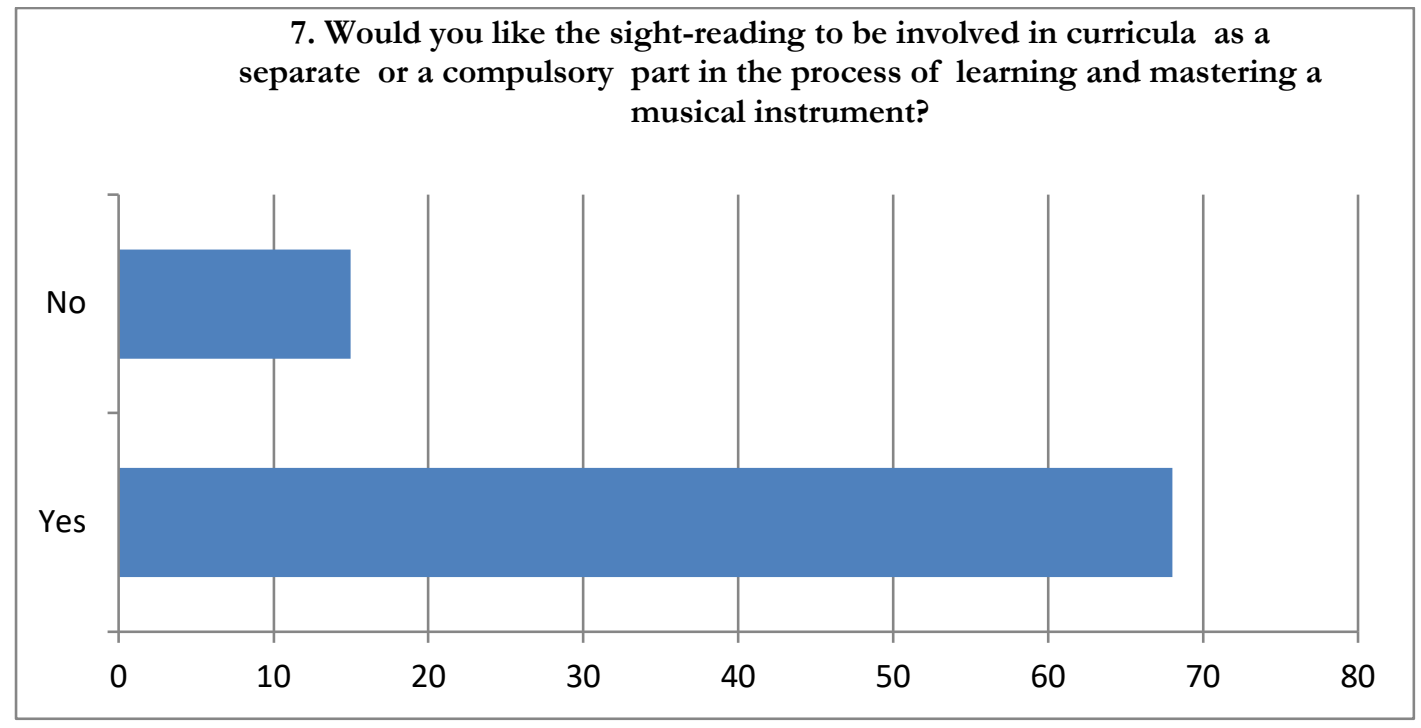


Chart 9.

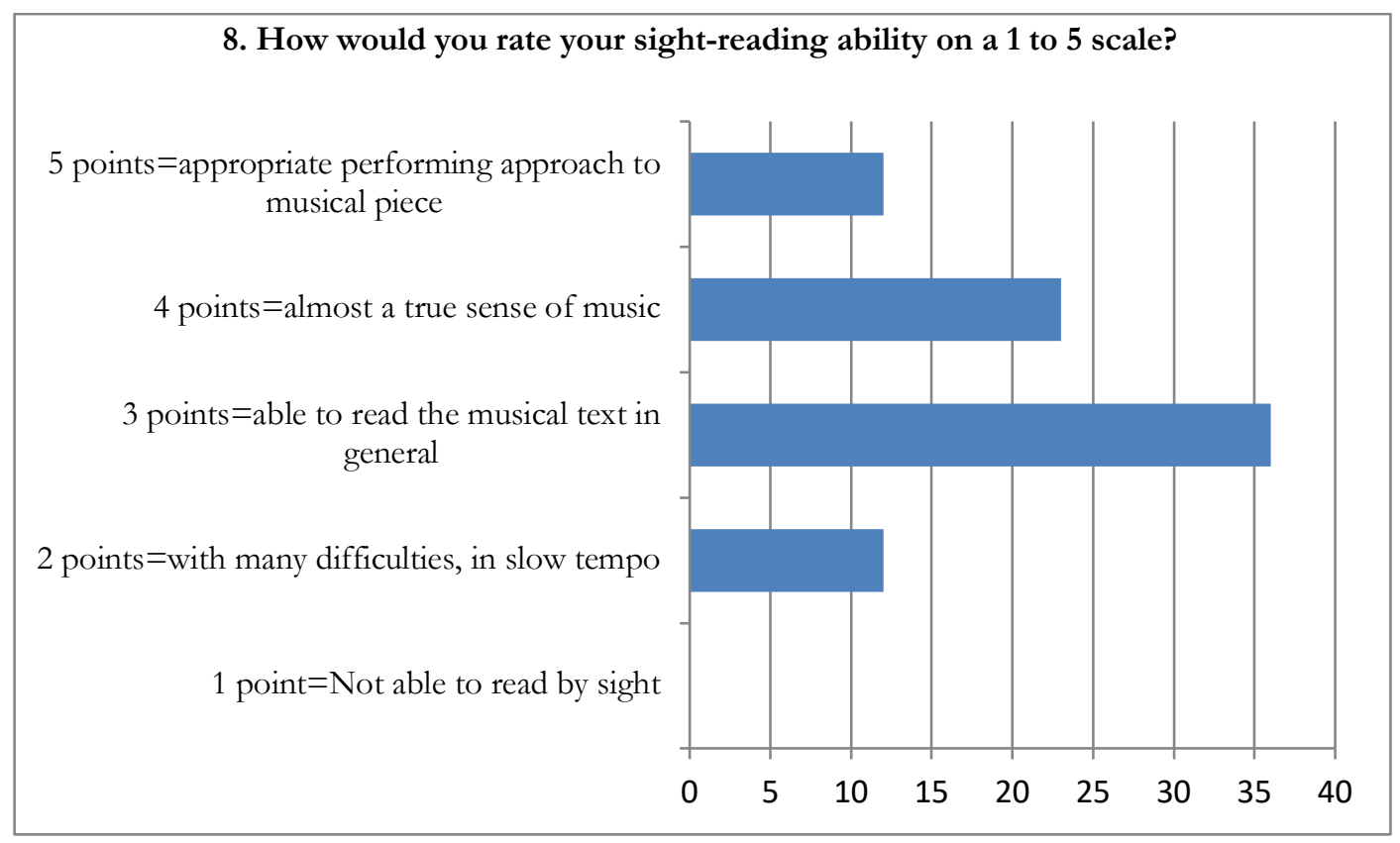

\section{Conclusion}

In conclusion, analyzing the responses of participants to the first four questions, our results show that they agree with our hypotheses. The answers to the fourth question reveal that $100 \%$ of respondents agree that the sight-reading has an important role in accompanying a song or choral music while the responses to the fifth question reflect their non-serious attitude toward the sightreading skill. The sixth question regarding the inclusion of sight-reading in the learning process indicates that the sight-reading is involved in the process of learning a musical instrument. Besides, the majority of respondents want the sight-reading to be involved in curricula as a separate or a compulsory course. Based on survey results, it should be noted that the respondents pay enough attention to the development of sight-reading skills in the process of learning a musical instrument.

In response to the rating question on the important skill of sight-reading, the majority of respondents consider themselves to be good sight-readers. However, this can be subjective as we haven't carried out a qualitative experiment.

In this study, we tried to compare a large number of Soviet, Post-Soviet and Western studies. It turns out that the methods and suggestions are generally the same while in learning process and self-directed training the sight-reading skill fails to get enough attention it deserves. It is important 
that along with so many studies and methods, the sight-reading is still a topical issue for musicians. On the one hand, there are all resources we need to deal with an issue more thoroughly, but on the other hand, we don't see proper attention to the sight-reading and consistent practice in the learning process and it is usually left to the discretion of the teachers.

The lecturer should highlight the importance of sight-reading in the learning process and be able to choose the right methods and musical compositions to motivate the students and develop the sight-reading skill by taking into account the student's abilities. Essentially, mastering a new composition already implies sight-reading skill and prior acquaintance with the musical work. However, the latter can't replace the sight-reading.

Since the sight-reading is not included in curricula and entirely depends on the lecturers' individual approach, a lecturer is expected to plan and work up methods in professional piano, accompaniment and general piano courses for developing the skill of sight-reading which will be an important stimulus to the professional growth of future teachers. Based on the results of our study, we can state that the hypotheses about the importance of sight-reading skill are fully supported. In conclusion, we can assure that the survey respondents recognize the importance of sight- reading in their work. Certainly, they will contribute to the development of this skill in the future. Generally speaking, the sight-reading is of great importance to every pedagogue, future music teacher and musician involved in performance. Moreover, it is important for the future music teacher to have the ability to sight-read and analyze the notes at first sight in order to identify favorite works when turning the sheet music pages and quickly get oriented to the choice of work. Certainly, it is impossible to learn to play or sing musical pieces and select them without having the ability of sightreading.

The sight-reading provides the opportunity of studying a wide range of music literature and getting a multi-styled and multifunctional playlist. In this regard, of course, the sight-reading ability plays a key role in the future music teacher's performing skills.

The sight-reading is an activity that opens up the most favorable and wide-ranging opportunities to get acquainted with music literature. Regularly in front of the sightreading musician, the works of various authors, artistic styles, and historical epochs shine through. Note that the musician in front of the piano is particularly advantageous; In addition to compositions for piano, he/she can also enjoy transcriptions and scores of operas, symphonic, chamber-instrumental and vocal compositions. In other words, sight- 
reading is, in essence, a constant and rapid change in musical perceptions, impressions, "revelations", an intense flow of rich and varied musical information (TSIPIN, 1984, p. 145-146).

Certainly, the instrumental performance is the most difficult thing which requires both an appropriate technical skills and artistic maturity. It is crucial to develop sight-reading skill both in schoolchildren and adult beginners already at the pedagogical university or college.

The development of sight-reading ability is also essential for the accompaniment which has a major role in the teacher's activities. Accordingly, it is absolutely necessary for music classes as well as for extracurricular activities and events.

The sight-reading skill expresses the teacher's high performing skills, the mature comprehension of the creative nature that the teacher should obtain not only before the pedagogical activity but also throughout the career by reaching perfection. It also improves the teacher's reputation in the eyes of the students and, as a result, they are filled with respect and admiration.

\section{ACKNOWLEDGEMENTS}

The author would like to thank all participants who enthusiastically took part in this study, and the two anonymous reviewers for helpful comments made about this study.

\section{REFERENCES}

ADAMYAN Anna, Music education issues for adult beginners in Armenia: specifically the analysis of the difficulties of piano playing. British Journal of Music Education, Volume 35, Issue 2, pp. 191202, July, 2018. https://doi.org/10.1017/S0265051717000249.

BRYANSKAYA Faina, Formirovanie i razvitiye navyka igry s lista v pervye godi obucheniya pianista [The formation and development of sight-reading skill in the early grades of pianist's learning process], Izdatelskiy dom Klassika-XXI, Moscow, 2005.

HAYWARD M. Carol and GROMKO E. Joyce, Relationships among Music Sight-Reading and Technical Proficiency, Spatial Visualization, and Aural Discrimination, Journal of Research in Music Education, Vol. 57, No. 1, pp. 26-36, 2009. 
KOSTKA J. Marilyn, The Effects of Error-Detection Practice on Keyboard Sight-Reading Achievement of Undergraduate Music Majors, Journal of research in Music Education, Volume 48, number 2, pp. 114-122, 2000.

KORYKHALOVA P. Natalya, Za vtorym royalem: Rabota nad muzikalnim proizvedeniyem v fortepiannom klasse [At the second piano: Working on a musical composition in a piano class], Saint Petersburg, 2006.

OSBORNE M.E. et al., The Idea bank: Teaching sight reading, Music Educators Journal, Vol. 62, no.7, (Mar., 1976), pp. 62-69, 1976.

OSBORNE. S. Margaret, Art in Motion III: Performing under pressure; chapter "Psychological skills to support performance under pressure”, Peter Lang, Frankfurt, pp. 93-114, 2016.

PENTTINEN Marjaana.; HUOVINEN Erkki., The Early Development of Sight-Reading Skills in Adulthood: A Study of Eye Movements, Journal of Research in Music Education 59(2), pp. 196 220, 2011.

PIKE D. Pamela., (2012), Sight-reading strategies: For The Beginning And Intermediate Piano Student: A Fresh Look At A Familiar Topic, American Music Teacher, Vol. 61, No. 4, pp. 23-28, February/March, 2012.

STEVEN L. Betts; CASSIDY W. Jane, Development of Harmonization and Sight-Reading Skills among University class piano students, Journal of research in music education, , Volume 48, Number 2, pp. 151-161, 2000.

TSIPIN M. Gennadiy, Obucheniye igre na fortepiano, [Learning piano playing], Moscow, 1984.

VERCHOLAZ Raisa, Voprosi metodiki chteniya not s lista [Questions concerning the methodology of sight-reading], Moscow, 1960.

YEGOROV Tikhon G., Psichologia ovladeniya navikom chteniya [Psycology of mastering the sight-reading skill], Moscow, 1953.

\section{ABOUT THE AUTHOR}

Anna Adamyan is a $\mathrm{PhD}$ in Arts, and Associate Professor of the chair of Music Education of Armenian State Pedagogical University (ASPU). She was born in 1980, and graduated as a pianist from Yerevan Komitas State Conservatory with honors in 2003. In 2012 she completed her doctorate study, and received a PhD degree in Musical Art in 2013. Anna Adamyan has 15 years of pedagogical experience as a piano teacher and accompanist. Her research interests include Armenian piano music history, performing arts, music psychology, music education, and piano teaching methods. ORCID: https://orcid.org/0000-0002-1484-4744. E-mail: adanna80zh@gmail.com 